\title{
PELAKSANAAN METODE PEMBELAJARAN KITAB KUNING DI PONDOK PESANTREN TARBIYAH ISLAMIYAH MALALO
}

\author{
Rosma Eka Putri \\ Operator SD Negeri 39 Batipuh \\ Kecamatan Batipuh Selatan Kabupaten Tanah Datar \\ e-mail: rosmaekaputri2016@gmail.com
}

\begin{abstract}
The purpose of this research was see the Implementation of Learning Methods Kitab Kuning at Islamic Boarding School Tarbiyah Islamiyah Malalo. This research was was qualitative research and with the type of research is field research that is descriptive qualitative. Data sources are principals, some ustadz / ustadzah, and some students of VIII grade. Techniques of collection of data such as observation, interview, and documentation. Analysis of data this is used to select data, classify data the content of the analysis, and withdrawal conclusion. The results found that, the methods was used in the implementation of Kitab Kuning learning with classical methods (combination of conventional methods) which learning has done in tiered and classy. The material is taught at Islamic boarding school Tarbiyah Islamiyah Malalo using kitab kuning with a combination of bandongan methods (santri listening or following what has delivered by ustadz), sorogan (ustadz listening / following what have santri), done to memorize (method to remember their lessons), discussion (to solve the problem of the material has being studied), qawa'id tarjamah (language proficiency ie writing, reading and translation), qiyasiyah (in qiyaskan first then bringing in examples), and istiqra'iyah (bringing the examples first followed by qawaid in general). The reason of the method is applied in learning kitab kuning Islamic Boarding School Tarbiyah Islamiyah Malalo is because it can make santri easy to understand the meaning learning kitab kuning.
\end{abstract}

Keywords: Method, Learning, Kitab Kuning, and Islamic Boarding School.

\section{PENDAHULUAN}

Penelitian ini berawal dari suatu realitas bahwa pesantren merupakan suatu lembaga pendidikan non-formal yang telah menjadi pusat pengajaran Islam. Pesantren merupakan lembaga pendidikan dengan bentuk khas sebagai tempat dimana proses pengembangan keilmuan, moral dan ketrampilan para santri menjadi tujuan utamanya. Sebagai lembaga pendidikan Islam, pesantren memiliki lima elemen penting yaitu pondok tempat menginap santri, masjid, santri, pengajaran kitab-kitab klasik (kitab kuning), dan Kyai (Abd. Muin M dkk, 2007:17). Pendidikan di pondok pesantren sangat identik dengan yang namanya pengajaran kitab kuning. Pengajaran kitab kuning adalah 
pelajaran pokok pesantren yang tujuannya untuk mengembangkan pengajaran agama Islam, karena kitab kuning pada umumnya dipahami sebagai kitab keagamaan berbahasa Arab, menggunakan aksara Arab yang dihasilkan oleh para ulama dan pemikir muslim di masa lampau khususnya yang berasal dari Timur Tengah, yang tujuannya untuk menambah dan memperdalam pemikiran bagi generasi yang akan datang (Azyumardi Azra, 2002:111). Pelaksanaan metode pembelajaran di pondok pesantren merupakan hal yang selalu mengalami perkembangan dan perubahan sesuai dengan penemuan metode yang lebih efektif dan efisien untuk mengajarkan masing-masing ilmu pengetahuan.

Dengan demikian, pembelajaran di pondok pesantren akan berlangsung dengan baik apabila ustadz dan ustadzah memahami berbagai metode atau cara bagaimana materi kitab kuning itu harus disampaikan pada santrinya, karena metode pembelajaran jauh lebih penting dari pada materi pembelajarannya. Begitu pentingnya metode pembelajaran dalam proses belajar mengajar, maka proses pembelajaran tidak akan berhasil dengan baik apabila ustadz dan ustadzah tidak menguasai metode pembelajarannya dengan baik, tetapi sebaliknya proses pembelajaran akan berhasil dengan baik apabila ustadz dan ustadzah nya menguasai metode dan materi pembelajarannya dengan baik.

Melihat kenyataan itulah peneliti tertarik meneliti di pondok pesantren Tarbiyah Islamiyah Malalo, yang dilakukan pada tingkat Madrasah Tsanawiyah Swasta (MtsS). Pada tingkat MtsS ini kurikulum yang digunakan adalah kurikulum pondok pesantren, dengan menerapkan kurikulum pondok pesantren ini diharapkan santri untuk bisa menguasai pembelajaran kitab kuningnya dengan maksimal, karena pada tingkat MtsS ini santri dan satriwati baru memasuki dan mendalami pembelajaran kitab kuning tersebut. Oleh karena itu ditetapkan kurikulumnya dengan kurikulum pondok tersebut, agar mereka bisa dengan mudah memahami pembelajaran kitab kuningnya. Implikasi dari penerapan kurikulum pondok pesantren ini adalah santri dan santriwati bisa dengan fasigh dan lancar dalam pemahaman dasar tentang pembelajaran kitab kuning tersebut.

$$
\text { Pada saat ustadz/ustadzah }
$$
mengajarkan kitab kepada santrinya, ustadz/ustadzah memulai pembelajarannya dengan membacakan tulisan yang ada di kitab tersebut dan menjelaskan cara membaca kitabnya, setelah dibacakan lalu dijelaskan maksud dari materi kitab tersebut, setelah itu 
ustadz/ustadzah meminta santri untuk membacanya secara bersama-sama dan terkadang ada yang diperintahkan untuk membacanya secara perorangan, dan terkadang ustadz/ustadzah adanya menuntut hafalan terhadap materi yang dipelajarinya. Berdasarkan realita tersebut maka penelitian ini dilakukan untuk melihat pelaksanaan metode pembelajaran kitab kuning di pondok pesantren Tarbiyah Islamiyah Malalo.

\section{KAJIAN TEORITIS}

\section{Pondok Pesantren}

Kata pondok pesantren terdiri dari dua kata, "pondok" dan "pesantren". Disinyalir akar kata pondok terambil dari bahasa Arab, "funduk" yang berarti hotel atau asrama (Hasbullah, 1999:40). M. Arifin memberikan defenisi pondok pesantren sebagai suatu lembaga pendidikan agama Islam yang tumbuh serta diakui masyarakat sekitar, dengan sistem asrama (komplek) di mana santri-santri menerima pendidikan agama melalui sistem pengajian atau madrasah yang sepenuhnya berada di bawah kedaulatan dari Leadership seorang atau beberapa orang kyai dengan ciriciri khas yang bersifat kharismatik serta independent dalam segala hal (Mujamil Qamar, 2005:2).

Lembaga Research Islam (pesantren luhur), sebagaimana dikutip oleh Mujamil Qamar, mendefenisikan pesantren sebagai "suatu tempat yang tersedia untuk para santri dalam menerima pelajaranpelajaran agama Islam sekaligus tempat berkumpul dan tempat tinggalnya". Dalam penelitian ini, Mujamil Qamar memberikan defenisi pesantren yang lebih singkat, yaitu "suatu tempat pendidikan dan pengajaran yang menekankan pelajaran agama Islam dan didukung asrama sebagai tempat tinggal santri yang bersifat permanent (Mujamil Qamar, 2005:2). Nurcholish Madjid mengatakan tujuan pembinaan santri pada pondok pesantren adalah membentuk manusia yang memiliki kesadaran tinggi bahwa ajaran Islam merupakan nilai-nilai yang bersifat menyeluruh. Selain itu produk pesantren diharapkan memiliki kemampuan tinggi untuk mengadakan respons terhadap tantangan-tantangan dan tuntutantuntutan hidup dalam konteks ruang dan waktu (Nurcholish Madjid, 1997:6).

Dengan demikian, pondok pesantren adalah suatu lembaga pendidikan Islam dengan menetap dalam asrama (pondok) dengan seorang kyai sebagai tokoh utama dan masjid sebagai pusat lembaga dan menampung peserta didik (santri), yang belajar untuk memperdalami suatu ilmu agama Islam. Pondok pesantren tidak membedakan tingkat 
sosial ekonomi orang tua peserta didik (santri), pendidikan orang tua peserta didik (santri), tetapi dengan menekankan pentingnya moral agama sebagai pedoman perilaku peserta didik (santri) sehari-hari, serta menekankan pentingnya moral keagamaan tersebut dalam menjalani kehidupan bermasyarakat.

\section{Pembelajaran Kitab Kuning}

Pemahaman tentang kitab kuning menurut bebebrapa tokoh yang selalu aktif melakukan penelitian untuk memberikan kontribusi terhadap perkembangan Islam, khususnya dalam dunia pesantren, menjelaskan bahwa: (1) Menurut Masdar F. Mas'udi, kitab kuning adalah karya tulis Arab yang ditulis oleh para sarjana Islam sekitar abad pertengahan, dan sering di sebut juga dengan kitab kuno. (2) Menurut Ali Yafie, kitab kuning adalah kitabkitab yang dipergunakan oleh dunia pesantren yang ditulis dengan huruf Arab dengan bahasa Arab atau Melayu, Jawa, Sunda, dan hurufnya tidak diberi tanda baca (harakat, syakal) (Ali Yafie, 1994:51). (3) Menurut Martin Van Bruinessen, kitab kuning adalah kitab-kitab klasik yang ditulis berabad-abad yang lalu. Kitab ini disebut di Indonesia sebagai kitab kuning. Sedangkan menurut pengertian istilah, kitab kuning adalah kitab atau buku berbahasa Arab yang membahas ilmu pengetahuan agama Islam seperti fiqih, ushul fiqih, tauhid, akhlak, tasawwuf, tafsiral-Qur'an dan ulumul Qur'an, hadis dan ulumul hadis, dan sebagainya yang ditulis oleh ulama-ulama salaf dan digunakan sebagai bahan pengajaran utama di pondok pesantren (Dawan Rahardjo, 1985:5556).

Dengan demikian, pengajaran kitab kuning merupakan bagian dari pengajaran agama Islam, yang bahan pengajarannya bersumber dari materimateri kitab yang disesuaikan dengan tingkat kemampuan kognitif seorang siswa, dan berisikan penjelasan tentang hubungan manusia dengan Allah SWT maupun hubungan manusia dengan sesamanya dan dengan alam sekitarnya. Dalam pembelajaran kitab kuning yang perlu ditanamkan terlebih dahulu pada siswa adalah keimanan yang teguh, sebab dengan adanya keimanan yang teguh akan menghasilkan ketaatan menjalankan kewajiban beragama.

\section{Metode Pembelajaran Kitab Kuning}

Metode secara etimologi berasal dari kata bahasa Yunani yaitu Methodos yang berasal dari kata meta dan hodos, kata meta berarti cara atau melalui, sedangkan hodhos berarti jalan. Sehingga metode berarti jalan yang harus dilalui, cara melakukan sesuatu atau prosedur (Sunhaji: 2009:38). Metode pembelajaran merupakan bagian dari strategi 
instruksional, metode pembelajran berfungsi sebagai cara untuk menyajikan menguraikan, memberi contoh, dan memberi latihan kepada siswa untuk mencapai tujuan tertentu, tetapi tidak setiap metode pembelajaran sesuai digunakan untuk mencapai tujuan pembelajaran tertentu. (Martinis Yamin, 2007:145).

Berdasarkan penjelasan di atas, agar tercapainya tujuan pembelajaran kitab kuning tersebut, maka ada beberapa metode dari beberapa pakar yang bisa digunakan dalam pengajaran kitab kuning, yaitu:

a. Metode Sorogan

Sorogan berasal dari kata sorog (bahasa Jawa) yang berarti menyodorkan, sebab setiap santri menyodorkan kitabnya di hadapan kyai, atau pembantunya (badal, asisten kyai) (Departemen Agama RI, 2003:38). Sistem sorogan ini termasuk belajar secara individual, dimana seorang santri berhadapan dengan seorang guru, dan terjadi interaksi saling mengenal di antara keduanya. Menurut Zamakhsyari Dhofier, semua pesantren tentu memberikan sistem metode sorogan tetapi hanya diberikan kepada santri-santri yang baru yang masih memerlukan bimbingan individual. Metode sorogan dalam pengajian ini merupakan bagian yang paling sulit dari semua metode pendidikan tradisional, sebab metode tersebut menuntut kesabaran, kajian, ketaatan dan disiplin pribadi dari murid (Zamakhsyari Dhofier, 2011:54)

b. Metode Bandongan (Wetonan)

Dalam sistem bandongan, seorang santri tidak harus menunjukkan bahwa ia mengerti pelajaran yang sedang dihadapi. para kyai biasanya membaca dan menerjemahkan kalimat-kalimat secara cepat dan tidak menerjemahkan kata-kata yang mudah. Dengan cara ini, kyai dapat menyelesaikan kitab-kitab pendek dalam beberapa minggu saja. Sistem bandongan karena di maksudkan untuk santri-santri tingkat menengah dan tingkat tinggi, hanya efektif bagi santrisantri yang telah mengikuti sistem sorogan secara intensif (Zamakhsyari Dhofier, 2011:54).

c. Metode Musyawarah / diskusi

Metode musyawarah atau dalam istilah lain Bahtsul Masail merupakan metode pembelajaran yang lebih mirip dengan metode diskusi atau seminar (Departemen Agama RI, 2003:43). Beberapa orang santri dengan jumlah tertentu membentuk halaqah yang dipimpin langsung oleh kyai atau ustadz, atau mungkin juga santri senior, untuk membahas atau mengkaji suatu persoalan yang telah ditentukan sebelumnya. Dalam pelaksanaanya, para santri dengan bebas mengajukan pertanyaan- 
pertanyaan atau pendapatnya. Dengan demikian metode ini lebih menitik beratkan pada kemampuan perseorangan di dalam menganalisis dan memecahkan suatu persoalan dengan argumen logika yang mengacu pada kitabkitab tertentu. Musyawarah dilakukan juga untuk membahas materi- materi tertentu dari sebuah kitab yang dianggap rumit untuk memahaminya (Zamakhsyari Dhofier, 2011:57).

d. Metode Qawä'id Tarjamah

Jenjang pengajaran Qawā'id Tarjamah (tata bahasa) dalam pembelajaran ilmu nahwu sebaiknya harus mempertimbangkan kegunaannya dalam memahami kitab-kitab berbahasa Arab. Pengajaran Qawā'id Nahw misalnya harus diawali dengan materi tentang kalimat sempurna (jumlah mufidab), namun rincian materi penyajian harus dengan cara mengajarkan tentang ism, fi'il, dan hurf. Demikian pula dalam pola ajarnya juga harus mengkaitkannya dengan kebutuhan untuk memahami kitab-kitab berbahasa Arab (Abd.Mu'in dkk, 2011:162 (Jurnal Online).

e. Metode Klasikal

Metode klasikal di pondok pesantren merupakan penyesuaian dari perkembangan sekolah formal modern. Metode ini hanya mengambil sistem sekolah umum dengan model berjenjang seperti Sekolah Dasar (Madrasah Diniyah Ibtidaiyah), Sekolah Menengah Pertama (Madrasah Diniyah Tsanawiyah), Sekolah Menengah Atas (Madrasah Diniyah Aliyah), dan Perguruan Tinggi (Ma"had Ali).Akan tetapi materi yang diajarkan pada pesantren tetap menggunakan kitab kuning dengan perpaduan metode bandongan, sorogan, hafalan, musyawarah dan sebagainya (Departemen Agama RI, 2003:45).

f. Metode Hafalan (Tahfizh)

Metode hafalan ialah kegiatan belajar santri dengan cara menghafal suatu teks tertentu di bawah bimbingan dan pengawasan kyai/ ustadz (Departemen Agama RI, 2003:46). Para santri diberi tugas untuk menghafal bacaan-bacaan dalam jangka waktu tertentu. Hafalan yang dimiliki santri ini kemudian dihafalkan dihadapan kyai/ustadz secara periodik atau insidental tergantung kepada petunjuk kyai / ustadz yang bersangkutan.

g. Metode Qiyasiyah

Thariqah qiyasy adalah thariqoh yang diadopsi dari thoriqoh terdahulu yang meliputi tiga langkah pengaplikasiannya yaitu guru mempermudah pembelajaran qawaid dengan menyebutkan qaidah-qaidah atau ta'rif dari unsur yang umum lalu ke yang khusus 
dengan mendatangkan sebagian contoh-contoh yang kemudian dengan contoh itu siswa disuruh berlatih, untuk mengetahui sejauh mana pemahaman siswa terhadap apa yang sudah dijelaskan mengenai qawaid tersebut. Namun stressing dari metode ini adalah mendatangkan hal-hal (qaidah) yang umum lalu kemudian dibawa ke hal-hal yang sifatnya juz'iah dengan memberi contoh langsung dari qawaid yang dimaksudkan.

h. Metode Istigra'iyah

Model istiqraiy ini kebalikan dari metode qiyasi. Metode ini mengajarkan dari hal-hal yang berbentuk juz'iyah ke bentuk yang lebih umum, maksudnya adalah pembelajaran tarakib mendatangkan contoh-contohnya terlebih dahulu kemudian diikuti dengan qawaid pada umumnya seperti yang ada dalam kitab alnahwu al-wadlifi, karena menurut metode ini pembelajaran qawaid kurang mendapatkan hasil yang maksimal kecuali dengan banyak memberikan latihan kepada siswa dari bab yang telah diberikan oleh guru.

\section{METODE PENELITIAN}

Penelitian ini dilaksanakan di Pondok Pesantren Tarbiyah Islamiyah Malalo. Penelitian ini menggunakan penelitian kualitatif. Menurut Sanafiah Faisal bahwa penelitian kualitatif adalah suatu prosedur penelitian yang menghasilkan datadata yang bersifat deskriptif dalam bentuk kata-kata tertulis atau lisan dari orang-orang dan perilaku yang dapat diamati (Lexi J. Moleong, 2006:3). Jenis penelitian yang penulis gunakan adalah penelitian lapangan atau field research yang bersifat deskriptif kualitatif. Sumber data yang di gunakan adalah sumber data primer dan sumber data sekunder (Sugiyono, 2008:225). Teknik pengumpulan data dilakukan secara observasi, wawancara, dan dokumentasi. Analisis data penelitian menurut Miles dan Huberman (1992:16), yakni: (1)Reduksi data (menyeleksi data yang akan di analisis), (2) Mengelompokkan data atas data observasi, wawancara, dan dokumentasi, (3) Melakukan analisis isi (content) untuk data observasi, wawancara, dan dokumentasi, (4) Dilakukan pembahasan data dan menginterpretasikan serta analisis data. (5) Penarikan kesimpulan/verifikasi terhadap semua data yang diperoleh selama penelitian. Sedangkan teknik menguji keabsahan datanya adalah triangulasi. Triangulasi yang digunakan peneliti adalah triangulasi Sumber, metode, dan waktu (Lexi J. Moleong, 2006:330374).

Pelaksanaan Metode Pembelajaran Kitab Kuning di Pondok Pesantren... ｜ 195 
HASIL PENELITIAN

PEMBAHASAN

1. Metode pembelajaran kitab kuning di Pondok Pesantren Tarbiyah Islamiyah Malalo

Hasil wawancara dengan ustadzah R.S.W, Selasa tanggal 16 Mei 2017 di rumahnya, menyatakan bahwa: "Mengenai metode pembelajaran kitab kuning tahu sedikit, mungkin bisa dikatakan tidak banyak, akan tetapi untuk pembelajaran kitab kuning seperti nahwu sharaf ada beberapa metode yang insya Allah saya tahu. Tentang berbagai macam metode dalam pembelajaran kitab kuning saya baru mendengar adanya metode sorogan, bondongan, dan lainnya. Ada menggunakan metode tapi tergantung kembali kepada apa materi pembelajaran yang akan diajarkan. Contohnya hari ini kita belajar misalnya belajar ilmu sarfi misalnya itu tergantung kepada judulnya seperti kalau pelajaran meng ilat atau yang lainnya, ya tergantung kembali kepada materinya. Setelah kita melihat materinya baru kita memutuskan apa yang cocok metode yang akan kita gunakan itupun kalau metodenya cocok untuk digunakan untuk materi tersebut, akan tetapi kalau tidak biasanya saya kembali kepada metode dasar yaitunya membacakan, menterjemahkan kemudian menjelaskan qawaidnya gitu, intinya itu adalah metode qawaid tarjamah. Karena tidak ada tuntutan dari sekolah untuk pembuatan silabus dan RPP maka kami tidak ada membuatnya."

Berdasarkan temuan penelitian di atas, bahwa dalam pembelajaran kitab kuningnya ustadz dan ustadzahnya hanya sekedar saja mengetahui tentang metode pembelajaran kitab kuning. Ustadz / ustadzah tidak ada membuat perencanaan pembelajaran secara tertulis (silabus dan RPP) untuk panduan mengajarkan pembelajaran kitab kuning kepada santrinya, tapi walaupun demikian rancangan metode untuk mengajarkan pembelajaran kitab kuning kepada santri itu pasti ada walaupun hanya rancangan tidak secara tertulis atau rancangan yang ada dalam fikirannya saja. Alasan ustadz dan ustadzah tidak ada membuat rancangan pembelajaran secara tertulis adalah karena tidak adanya tuntutan untuk pembuatan RPP tersebut dari pihak Pondok Pesantren. Sedangkan metode yang biasa digunakan dalam pelaksanaan pembelajaran kitab kuning di pondok pesantren Tarbiyah Islamiyah Malalo adalah metode klasikal.

Dalam kapasitasnya sebagai pesantren salaf, pondok pesantren hendaknya tetap menyelenggarakan pendidikan sebagai ciri khasnya yang berorientasi pada materi keagamaan 
dengan kajian kitab-kitab kuning. Sistem pembelajaran yang digunakan adalah bandongan, sorogan, diskusi, klasikal, dan yang lainnya. Sistem klasikal yang dimaksud adalah sistem yang mengacu pada sekelompok kitab-kitab kajian tertentu, yang kemudian dikenal dengan istilah muhadhoroh (Rodliyah Zaenuddin, Jurnal Holistik: Vol.13 Nomor 01).

2. Penerapan metode pembelajaran kitab kuning di Pondok Pesantren Tarbiyah Islamiyah Malalo

Hasil wawancara dengan ustadzah A.H, Rabu 10 Mei 2017 di ruangan asrama santri, menyatakan bahwa: "Menggunakan metode Qawa'id Tarjamah, terkadang campuran Istiqraiyah. Setiap kali pertemuan metodenya sama, tetapi sesuai dengan kebutuhan, kalau seandainya butuh praktek berarti beda metodenya, beda atau tidaknya metode itu tergantung materi. Qawa'it Tarjamah itu dibacakan, ditarjamahkan, dan disuruh anakanak membaca. Media yang digunakan cuma buku, kitab, papan tulis, kadang-kadang laptop juga ada. Evaluasinya kadang-kadang disuruh misalnya guru membacakan setelah itu menguji anak-anak itu mengerti tidak mengertinya disuruh guru membacakan pengertian, pemahaman, surahnya, atau keterangannya ditanyakan sama murid mengerti ngak sama yang di baca, kadang- kadang kan cuma paham bacaan tapi surahnya atau keterangannya tidak mengerti, jadi ditanya seperti itu, karena pembelajaran kitab itu bukan cuman dibaca saja tapi paham dengan surahnya juga. Dalam menerangkan materi mendekatkannya dengan contoh, kalau hanya dibacakan saja terkadang siswa itu cuma mengerti yang dibacakan tapi kalau dicontohkan lebih paham kalau diberikan dengan contoh."

Berdasarkan temuan penelitian di atas, metode yang diterapkan yaitu melalui metode klasikal (perpaduan metode konvensional) yang pembelajarannya berjenjang dan berkelas-kelas. Yang mana materi yang diajarkan pada pondok pesantren Tarbiyah Islamiyah Malalo tersebut tetap menggunakan kitab kuning dengan perpaduan metode bandongan (santri menyimak atau mengikuti apa yang disampaikan ustadz), sorogan (ustadz menyimak/mengikuti apa yang disampakan santri), hafalan (metode untuk mengingat materi ajar), diskusi (sebagai pemecahan masalah dari materi yang dipelajari), Qawa'id Tarjamah (kemahiran berbahasa yakni kemahiran menulis, membaca dan menerjemahkan), Qiyasiyah (di qiyaskan terlebh dahulu baru setelah itu mendatangkan contoh-contoh), dan istigra'iyah (mendatangkan contoh-contohnya terlebih dahulu kemudian diikuti dengan qawaid 
pada umumnya). Tujuan metode yang diterapkan tersebut bisa membuat santrinya lebih mudah paham terhadap materi pembelajaran kitab kuning yang diajarkan.

Langkah-langkah tertentu yang digunakan ustadz/ustadzah dalam penerapan pembelajaran kitab kuningnya adalah pertama-tama ustadz/ustadzah dan santri sama-sama membuka kitab pada materi yang akan dipelajarinya, setelah itu ustadz/ustadzah membacakan bahasa Arab dan mengartikannya beberapa kali. Setelah itu, ustadz/ustadzah memerintahkan santri untuk membacanya baik itu secara bersama ataupun perorangan, setelah itu ustadz/ustadzah menjelaskan maksud dari materi yang telah dipelajari tersebut, dalam penjelasan materi tersebut juga terdapat tanya jawab antara ustadz/ustadzah dengan para santri, setelah itu terkadang juga terdapat tuntutan hafalan terhadap materi yang bisa di tuntut untuk hafalan.

Metode yang akan digunakan dalam pembelajaran kitab kuning itu disesuaikan dengan materi yang akan diajarkan serta sesuai dengan kemampuan ustadz dan ustadzah dalam menggunakan setiap metode dalam pembelajaran. Karena itulah peneliti beranggapan bahwa metode yang digunakan ustadz dan ustadzah dalam mengajarkan pembelajaran kitab kuning yaitu dengan menggunakan metode klasikal (perpaduan metode konvensional) yang pembelajarannya dilakukan secara berjenjang dan berkelas-kelas. Ini didapatkan dari hasil observasi dan wawancara yang penulis lakukan kepada ustadz dan ustadzah yang mengajarkan kitab kuning tersebut. Metode klasikal di pondok pesantren merupakan penyesuaian dari perkembangan sekolah formal modern, metode ini hanya mengambil sistem sekolah umum dengan model berjenjang. Akan tetapi materi yang diajarkan pada pesantren tetap menggunakan kitab kuning dengan perpaduan dari beberapa metode dibawah ini:

a. Perpaduan dari metode bandongan (santri menyimak atau mengikuti apa yang disampaikan ustadz), metode sorogan (ustadz menyimak/mengikuti apa yang disampakan santri), dan metode diskusi (sebagai pemecahan masalah dari materi yang dipelajari).

b. Perpaduan dari metode bandongan (santri menyimak atau mengikuti apa yang disampaikan ustadz), metode diskusi (sebagai pemecahan masalah dari materi yang dipelajari) dan metode hafalan (metode untuk mengingat materi ajar).

c. Perpaduan dari metode Qawa'id Tarjamah (kemahiran berbahasa yakni kemahiran menulis membaca 
dan menerjemahkan), metode diskusi (sebagai pemecahan masalah dari materi yang dipelajari), dan metode hafalan (metode untuk mengingat materi ajar).

d. Perpaduan dari metode Qiyasiyah (di qiyaskan terlebih dahulu baru setelah itu mendatangkan contohcontoh), dan metode Qawa'id Tarjamah (kemahiran berbahasa yakni kemahiran menulis, membaca dan menerjemahkan).

e. Perpaduan dai metode Istiqra'iyah (mendatangkan contoh-contohnya terlebih dahulu kemudian diikuti dengan Qawaid pada umumnya), dan metode Qawa'id Tarjamah (kemahiran berbahasa yakni kemahiran menulis, membaca dan menerjemahkan).

f. Perpaduan dari metode Qiyasiyah (di qiyaskan terlebih dahulu baru setelah itu mendatangkan contohcontoh), metode Qawa'id Tarjamah (kemahiran berbahasa yakni kemahiran menulis, membaca dan menerjemahkan), metode diskusi (sebagai pemecahan masalah dari materi yang dipelajari), dan metode hafalan (metode untuk mengingat materi ajar).

g. Perpaduan dai metode Istiqra'iyah (mendatangkan contoh-contohnya terlebih dahulu kemudian diikuti dengan Qawaid pada umumnya), metode Qawa'id Tarjamah (kemahiran berbahasa yakni kemahiran menulis, membaca dan menerjemahkan), dan metode diskusi (sebagai pemecahan masalah dari materi yang dipelajari).

3. Alasan metode klasikal yang diterapkan dalam pembelajaran kitab kuning di Pondok Pesantren Tarbiyah Islamiyah Malalo

Hasil wawancara dengan ustadz N.Y, Minggu 4 Mei 2017 di ruangan kantor guru, menyatakan bahwa: "Karena metode tersebut yang saya anggap cocok untuk penunjang pembelajaran, karena metode tersebut bisa membuat siswa lebih mudah untuk memahami pembelajaran. Kelebihannya bisa membuat siswa menguasai pembelajaran dan paham terhadap materi pembelajaran. Kelemahannya membuat anak malas karena metode itu-itu saja. Langkah selanjutnya yang diambil untuk menutupi kekurangannya dengan cara melakukan pengulangan terhadap materi sebelum pembelajaran dilanjutkan. Tetapi dari metode yang diterapkan tersebut Alhamdulillah kebanyakan siswa bisa memahami pembelajaran dan nilainya bagus-bagus semua."

Berdasarkan temuan penelitian di atas, bahwa penyebabnya adalah karena metode tersebut bisa membuat santri lebih mudah untuk memahami materi pembelajaran kitab kuningnya, karena metodenya tidak berbelit-belit 
dan juga karena keterbatasan pengetahuan dan pemahaman $u s t a d z$ dan ustadzah tentang berbagai metode yang bisa digunakan dalam pembelajaran kitab kuning tersebut. Pada Pondok Pesantren Tarbiyah Islamiyah Malalo menggunakan berbagai metode dalam pembelajaran kitabnya untuk membuat santrinya mudah memahami materi pembelajaran kitab kuning yang merupakan tulisan Arab gundul, yang jika tidak serius mempelajarinya akan susah untuk dipahami dan di mengerti, karena tulisannya dalam bentuk bahasa arab yang tidak memiliki baris dan tidak memiliki maknanya. Metode yang digunakan tersebut bisa membuat anak mengerti apa artinya, yaitunya lebih kepada pemahaman santri dari segi makna atau artinya dalam pembelajaran kitab kuning tersebut. Metode ini merupakan metode yang mempermudah santri untuk memahami pembelajaran kitab kuningnya.

\section{PENUTUP}

\section{Kesimpulan}

Metode yang digunakan dalam pelaksanaan pembelajaran kitab kuning di Pondok Pesantren Tarbiyah Islamiyah Malalo menggunakan metode klasikal dengan perpaduan metode konvensional yang pembelajarannya dilakukan secara berjenjang dan berkelas-kelas. Materi yang diajarkan tetap menggunakan kitab kuning dengan perpaduan metode bandongan, sorogan, hafalan, diskusi, qawa'id tarjamah, qiyasiyah, dan istiqra'iyah. Dengan menggunakan beberapa langkah, yaitu pertama ustadz/ustadzah dan santri sama-sama membuka kitab pada materi yang akan dipelajarinya, setelah itu ustadz/ustadzah membacakan bahasa Arab dan mengartikannya beberapa kali, lalu memerintahkan santri untuk membacanya baik itu secara bersama ataupun perorangan, setelah itu ustadz/ustadzah menjelaskan maksud dari materi yang telah dipelajari tersebut, dalam penjelasan materi tersebut juga terdapat tanya jawab antara ustadz/ustadzah dengan para santri, setelah itu terkadang juga terdapat tuntutan hafalan. Alasan metode klasikal diterapkan karena bisa membuat santri mudah mengerti atau paham apa artinya, yaitunya lebih kepada pemahaman santri dari segi makna dalam pembelajaran kitab kuning.

\section{Saran}

Sebelum mengajarkan kitab kuning kepada santri hendaknya ustadz/ustadzah membuatkan suatu rancangan (perangkat pembelajaran) agar bisa menunjang tercapainya tujuan dari pembelajaran kitab kuning tersebut.

Hendaknya 
ustadz/ustazdah

selalu

memperhatikan metode pembelajaran yang tepat, berfariasi, dan bisa memberikan motivasi belajar santri untuk meningkatkan prestasi belajar kitab kuningnya. Agar tercapainya tujuan pembelajaran dengan baik hendaknya ustadz/ustadzah selalu memperhatikan para santri dengan memperbaiki dan lebih meningkatkan kualitas pengajaran kitab kuning kedepannya.

\section{KEPUSTAKAAN ACUAN}

Azra, Azyumardi. 1999. Pendidikan Islam. Ciputat: PT. Logos Wacana Ilmu.

Azra, Azyumardi. 2002. Pendidikan Islam Tradisi dan Modernisasi Menuju Melinium Baru. Jakarta: Logos Wacana Ilmu.

Departemen Agama RI. Direktorat Jenderal Kelembagaan Agama Islam. Direktorat Pendidikan Keagamaan dan Pondok Pesantren Proyek Peningkatan Pendidikan Luar Sekolah pada Pondok Pesantren, 2003,Pola Pengembangan Pondok Pesantren. Jakarta: Depag RI.

Departemen Agama RI. 2003. Pondok Pesantren dan Madrasah Diniyah. Jakarta: Direktorat Jenderal Kelembagaan Agama Islam.

Dhofier, Zamakhsyari. 2011. Tradisi Pesantren: Studi Tentang
Pandangan Hidup Kyai, Edisi Revisi. Jakarta: LP3ES.

Hasbullah. 1999. Kapita Selekta Pendidikan Islam. Jakarta: Rajawali Pers.

Madjid, Nurcholish. 1997. Bilik-Bilik Pesantren "Sebuah Potret Perjalanan". Jakarta: Paramadina.

Mathey, Miles.B and Huberman. 1992. Qualitativ Data Analisys. etjep: Penterjemah: Rohendi Rohid, Jakarta : UI Press.

Moleong, Lexi J. 2006. Metode Penelitian Kualitatif. Bandung: Remaja Rosdakarya.

Mu'in, Abd. dkk, 2011, Efektivitas Ilmu Nahw Dalam Pembelajaran Bahasa Arab, Vol.8, No.1 (Jurnal Online), diakses pada tanggal 20 Juli 2017.

Muin, Abd. dkk. 2007. Pesantren dan Pengembangan Ekonomi Umat. Jakarta: CV . Prasasti.

Purwanto, Ngalim. 2008. PrinsipPrinsip Evaluasi Pengajaran. Bandung: Bumi Aksara.

Qamar, Mujamil. 2005. Pesantren dari Transformasi Metodologi Menuju Demokratisasi Institusi. Jakarta: Erlangga.

Rahardjo, Dawam. 1985. Pergulatan Dunia Pesantren. Jakarta: P3M.

Rodliyah Zaenuddin, 2012/1434 H, Pembelajaran Nahwu dan Sharaf dan Implikasinya Terhadap 
Membaca dan Memahami Sunhaji. 2009. Strategi Pembelajaran, Literatur Bahasa Arab Konsep, dasar, Metode, dan Aplikasi Kontemporer Pada Santri Dalam Proses Belajar Mengajar. Pesantren Majlis Tarbiyatul Yokyakarta: Grafindo Lintera Mubtadi-Ien (MTM) Desa Media.

Kempek Kecamatan Gempol Tim Direktorat Jenderal Kelembagaan Kabupaten Cirebon, Holistik Agama Islam. 2003. Pola Vol.13 nomor 01, (Jurnal Online), Pembelajaran di Pesantren. Jakarta: diakses pada tanggal 20 Juli 2017.

Direktorat Jenderal

Kelembagaan Agama Islam.

Sugiyono. 2008. Metode Penelitian Kuantitatif Kualitatif dan RED. Bandung:Alfabeta.

Sudjana, Nana. 2000. Dasar-dasar Proses Belajar Mengajar. Bandung: Sinar BaruAlgensindo, Cet.Kelima.

Yafie, Ali. 1994. Menggagas Fiqih Sosial. Bandung: Mizan.

Yamin, Martinis. 2007. Desain Pembelajaran Berbasis Tingkat Satuan Pendidikan. Jakarta: Putara Grafika. 